\title{
Evaluation of Natural Gas Saving Measures in Public Educational Institutions
}

\author{
Volodymyr Pashkevich, Yuriy Furdas*, Volodymyr Craiovsky, Vasyl Zhelykh \\ Lviv Polytechnic National University, 12 Stepana Bandery St., Lviv, 79013, Ukraine
}

Received: September 17, 2020. Revised: October 12, 2020. Accepted: October 19, 2020.

(C) 2020 The Authors. Published by Lviv Polytechnic National University.

\begin{abstract}
The article analyzes the data of gas consumption for the heating periods and confirms that for the actual outdoor air temperatures there is a decrease in gas consumption. Necessary heat loads and gas consumption were determined to ensure the required indoor air temperature in the premises of the educational buildings with the proposed mode of gas savings by lowering the indoor air temperature, the so-called economical mode of operation of the boiler room. The theoretical economy of gas from lowering the temperature regime is determined. To increase the accuracy of the experiment, the comparison of the amount of gas consumed was performed in terms of working and non-working periods of the day. Based on these studies, it should be noted that the actual plot can be used to determine the actual gas savings in real conditions.
\end{abstract}

Keywords: boiler room; air temperature; boiler gas; natural gas.

\section{Introduction}

Ensuring energy saving in higher education is characterized by its multi-vector nature. Only a detailed analysis of each of the approaches to solving the problem of energy saving will determine the priority areas to take into account the specifics of the university. One of the ways to solve the problems of energy saving is the organizational mechanisms to ensure measures for the rational use of fuel and energy resources, the introduction of measures for thermal renovation and the introduction of innovative heat supply technologies. It was noted that certain changes in this mechanism give rise to its adaptation to international regulatory levers and improvement, which provides a certain level of deregulation of energy saving policy, stimulates economic sustainability and implementation of initiatives of individual higher education institutions [1].

In [2] the issues of increasing the level of energy security of higher educational institutions were considered. The author argues that for the full realization of the potential of energy efficiency of universities requires a purposeful policy of university management, which will allow for systematic control and management of energy resources of universities. The main tool for energy management can be a program-targeted method, the use of which is due to the complex nature of the problem and the need to coordinate the actions of all departments and services of higher education and contribute to the development of general technical policy and efficiency of budget resources.

There are works [3] which consider in detail the main energy saving measures that can be implemented in higher education, in particular: replacement and modernization of power supply and lighting systems; re-equipment and change of modes of operation of heating, hot water supply, ventilation and air conditioning systems; modernization of boiler equipment. Unfortunately, the implementation of these measures for the university budget remains too high, despite significant energy savings.

${ }^{*}$ Corresponding author. Email address: yurii.v.furdas@1pnu.ua

This paper should be cited as: V. Pashkevich, Y. Furdas, V. Craiovsky, V. Zhelykh. Evaluation of natural gas saving measures in public educational institutions. Energy Engineering and Control Systems, 2020, Vol. 6, No. 2, pp. 88 - 96. https://doi.org/10.23939/jeecs2020.02.088 
An important point is the use of alternative energy sources for energy supply of universities. Thus, in order to reduce the consumption of traditional fuel and energy resources, solar hot water supply systems (SS GWP) have been installed at the Petro Mohyla Black Sea State University on the main building and dormitories, which partially meet the needs for hot water. The introduction of solar hot water systems in educational institutions is of particular importance for their promotion among students and staff through free solar energy on a real example - the introduction of solar systems for hot water supply. The use of solar energy instead of electricity for hot water supply can reduce electricity consumption at the university for the year by $4.6 \%$ [4]. Unfortunately, the use of solar energy to meet the needs of hot water in relation to the time of its maximum need is problematic, because the time with the greatest solar radiation falls on the holiday period.

The expediency of using another type of alternative energy sources - a heat pump - was analyzed. The combined use of a heat pump and electric heating in the premises of educational institutions was considered [5]. The use of such systems is most appropriate in temperate climates. As a result of operation, the heat pump takes over $70 \%$ of the heat load during the heating period. And only in the event of cold weather with low temperatures $\left(-15^{\circ} \mathrm{C}\right.$ and below) it is necessary to use an electric boiler. As a result of the operation of combined heating systems, operating costs are reduced and the appropriate level of comfort is maintained. Unfortunately, for geographical areas with relatively low outdoor temperatures in the cold season, the use of such systems is not very effective.

An integrated approach to energy supply is also very effective. Thus, in particular, Oles Honchar Dnipropetrovsk National University implemented an innovative project aimed at improving the energy efficiency of the lecture hall, which was supposed to save energy by reducing the consumption of fossil fuels through the use of energy from alternative sources, heat recovery and exhaust emissions, heating, ventilation and air conditioning of the training unit [6].

The proposed technical solutions are characterized by a comprehensive approach to solving several problems: the use of solar radiation energy; accumulation of heat in the seasonal soil accumulator; organization of heat extraction from outside and exhaust air; heat recovery in the supply and exhaust ventilation system. New in the circuit solution is the use of energy-efficient fences to solve the above problems.

In the works [7]-[9] the analysis of influence of the administrative decisions directed on introduction of resourcesaving technologies in activity of higher educational institutions is carried out. The expediency of applying a comprehensive approach to energy efficiency management of universities, which combines economic, social and environmental factors, is substantiated. It was emphasized that achieving a real increase in energy efficiency of universities should be based not only on technical solutions, but also on more modern sustainable system management, as a tool that can save money through a competent resource-saving policy at all levels [7], [8].

The energy management system is also one of the components of the overall management system [10]. The introduction of the organization of management of energy consumption and energy saving (PEE) in the field of education requires its systematic implementation in higher education [11], [12]. The authors propose a conceptual model of PEE management, which provides: creation and support of appropriately adapted systems for collecting and monitoring information on energy consumption, methods of assessing energy efficiency with their support and adjustment to the conditions of practical implementation, use of in-depth energy audit schemes based on integrated energy models, and the development of detailed instrumental and computational studies of the energy condition of building elements. Studies were conducted taking into account the factors that affect the heat consumption of educational buildings, in particular: the duration of the heating season; glazing coefficients of buildings; the number of people in the buildings; values of thermal resistances of external protections and many others. Statistical methods of data processing were used [13], [14]. Such measures require consistency in solving complex management tasks, completeness and reliability of information on energy and operational performance of subordinate facilities.

The application of such a scientific and methodological approach aimed at improving energy efficiency in educational institutions makes it possible to rank buildings depending on energy efficiency; plan the volume of energy consumption and identify premises with atypical energy consumption; to carry out a rapid assessment of the implementation of energy efficiency measures and to receive an assessment of the effectiveness of the implementation of measures before the energy audit. In addition, software platforms and database management systems used in automated energy efficiency management systems are offered [15]. Software forms of input-output of 
information, its collection and analysis of energy use of objects are created. Management decisions allow optimizing the educational process taking into account the efficiency of the university's auditorium fund and control of energy costs, especially during the heating period [16]-[18]. To this end, it is necessary to introduce monitoring of the effectiveness of the use of the auditorium fund of the university to ensure the best planning of the functioning of energy supply systems and management of energy expenditures in the face of significant tariff increases. It is necessary to actively implement cost-effective organizational methods of regulating energy consumption by shifting the training and production process in time - in daylight (saving electricity for lighting) and warm part of the year (saving heat), extending winter holidays and reducing summer proportions.

\section{Goal of research work}

Having conducted an in-depth analysis of the current state of use of energy-saving technologies in universities, we can conclude that the problem remains very relevant and requires further study and a comprehensive approach to reducing energy consumption.

The most common way of saving is the introduction of the so-called intermittent mode of heat supply of the premises, the essence of which is that during working hours the room temperature is maintained in accordance with sanitary norms $18 \mathrm{0C}$, and during non-working hours (night and weekends) leads to a reduction in the consumption of fuel and energy resources. A few hours before the start of the working day, the temperature of the coolant increases above the level typical for working hours, in order to ensure the temperature in the premises in accordance with sanitary and hygienic standards. However, this mode saves up to 5.7\% of thermal energy [19].

Given the relatively small percentage of thermal energy savings, there is a need to study and implement more radical methods of saving heat and gas by introducing long vacations in schools.

The object of the research is the heat supply system of the educational buildings of Lviv Polytechnic National University, which are heated by its own gas boiler house. In total, the heat consumption system consists of 17 educational buildings. The total heat load of educational buildings is $8.0091 \mathrm{Gcal} / \mathrm{h}$. The boiler house from which heat supply is carried out is equipped with two hot water boilers with a heat productivity of $8.3 \mathrm{Gcal} / \mathrm{h}$ each. Passport efficiency of the boiler is $90 \%$.

\section{Presentation and discussion of research work results}

In accordance with the requirements of paragraph 5.3. DBN B2.5-67: 2013 "Heating, ventilation and air conditioning" [3] the internal temperature of the premises was reduced by $33.33 \%$ from $+18{ }^{\circ} \mathrm{C}$ to $+12{ }^{\circ} \mathrm{C}$.

Maintenance of the required temperature in the premises of educational buildings was carried out with the help of individual heating points, which are equipped with weather-dependent automation. The measurement of the internal temperature in the premises of the educational buildings was carried out using a temperature meter TESTO, by daily monitoring.

During the experiment in the boiler room every hour with the help of electronic meters were measured outside air temperature, coolant parameters, as well as recorded the hourly gas flow using a gas corrector "Universal-2M". The parameters of the boiler coolant were carried out in accordance with the schedule of qualitative regulation of the coolant temperature converted to the indoor air temperature in the room equal to $+12{ }^{\circ} \mathrm{C}$.

Experimental studies were conducted during the heating season of 2019. The evaluation of the results of the experiment was carried out in two ways:

- Determination of theoretical gas savings from lowering the temperature;

- Determining the actual gas savings by plotting the hourly gas consumption for previous periods, according to gas consumption data for previous similar periods, in the range of outdoor air temperatures from $+8{ }^{\circ} \mathrm{C}$ to $-19{ }^{\circ} \mathrm{C}$ and comparing them with the actual gas consumption during the experiment. To increase the accuracy of the experiment, the comparison of the amount of gas consumed was performed in terms of working and non-working periods of the day and month, which were used in previous periods. 
According to the schedule of qualitative regulation of temperature of the heat carrier (Fig.1) the main (working) mode of release of the heat carrier was supported from midnight to 01:00 pm on weekdays, and the saving mode of release of the heat carrier was maintained from 01:00 pm till midnight and at the weekends.

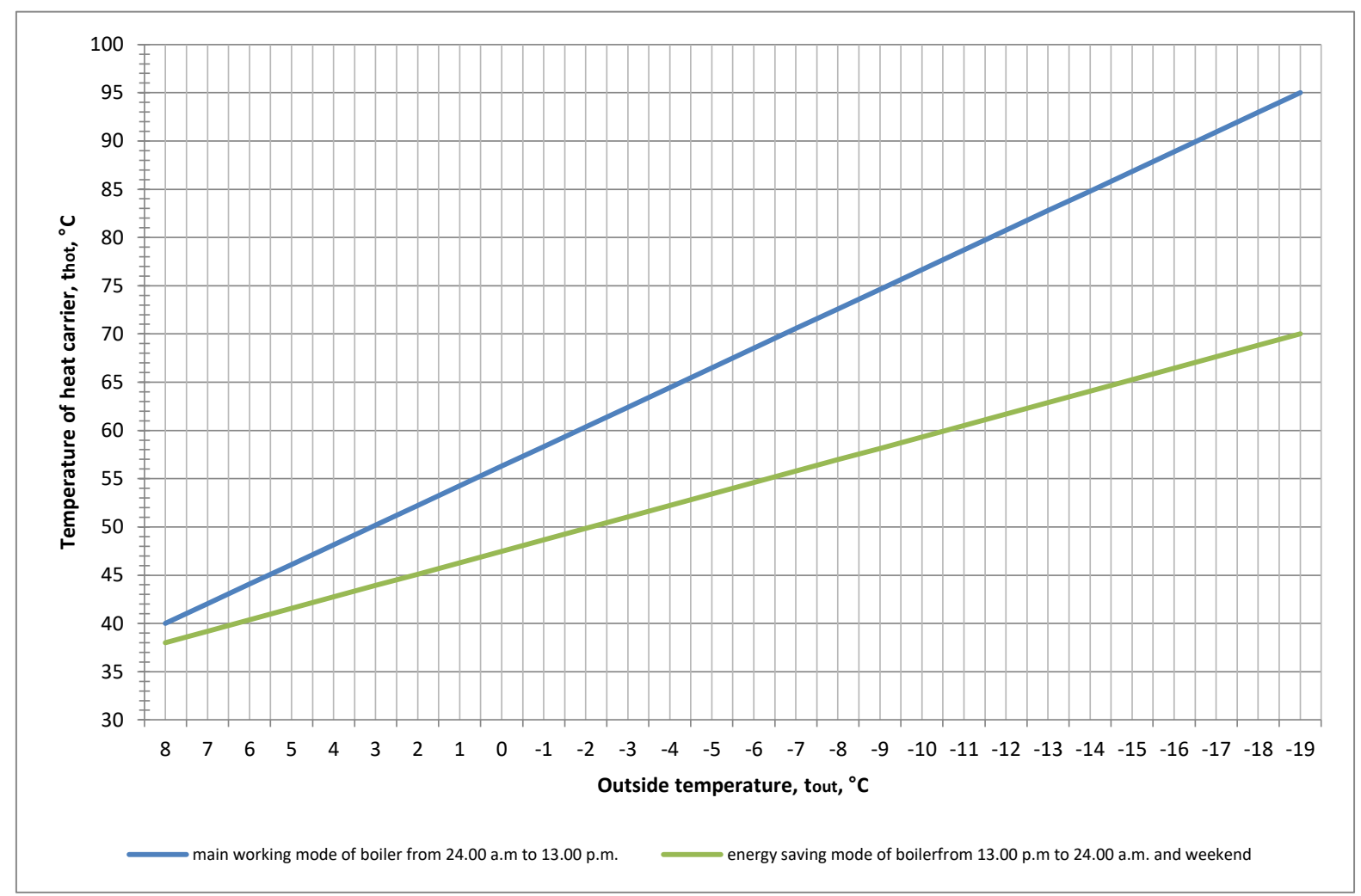

Fig.1. The schedule of qualitative regulation of temperature of the heat carrier in the giving highway from a boiler room.

Therefore, on the graph of the actual use of gas for previous periods (Fig.2), two graphical dependencies were built - for the main and savings mode of heat release from the boiler room. Experimental data on the actual hourly gas flow rate at specific measured outdoor air temperatures during the experiment were compared with the amount of gas consumed at similar outdoor air temperatures according to the graphs in Fig.2. Thus, the difference between the amount of hourly gas consumption for previous periods and the amount of gas consumed during the experiment will be equal to the value of the actual savings.

In the process of determining the theoretical gas economy, the hourly heat load of the boiler room was calculated for each point of the schedule of qualitative regulation of the coolant temperature (Fig.1) in the range of outdoor air temperatures from $+8{ }^{\circ} \mathrm{C}$ to $-19^{\circ} \mathrm{C}$. For this purpose, the average hourly heat flux for heating needs during the heating period $Q_{\text {mid. }}$ [21], [22] was calculated:

$$
Q_{\text {mid. }}=\frac{Q_{\max } \times\left(t_{\text {in }}-t_{\text {out.hp }}\right)}{\left(t_{\text {in }}-t_{\text {out.c }}\right)}, \mathrm{Gcal} / \mathrm{h}
$$

where $Q_{\max }$ is maximum heat load, Gcal / h; $t_{\text {in }}$ is estimated indoor temperature $\left(t_{\text {in }}=18^{\circ} \mathrm{C}\right)$; $t_{\text {out.hp }}$ is average air temperature of the heating period $\left(0.7^{\circ} \mathrm{C}\right)$; $t_{\text {out.c }}$ is calculated outdoor air temperature $\left.{ }^{\circ} \mathrm{C}\right)$.

As a result of calculations, it was found that the average hourly heat flux for heating was $3.74 \mathrm{Gcal} / \mathrm{h}$. 


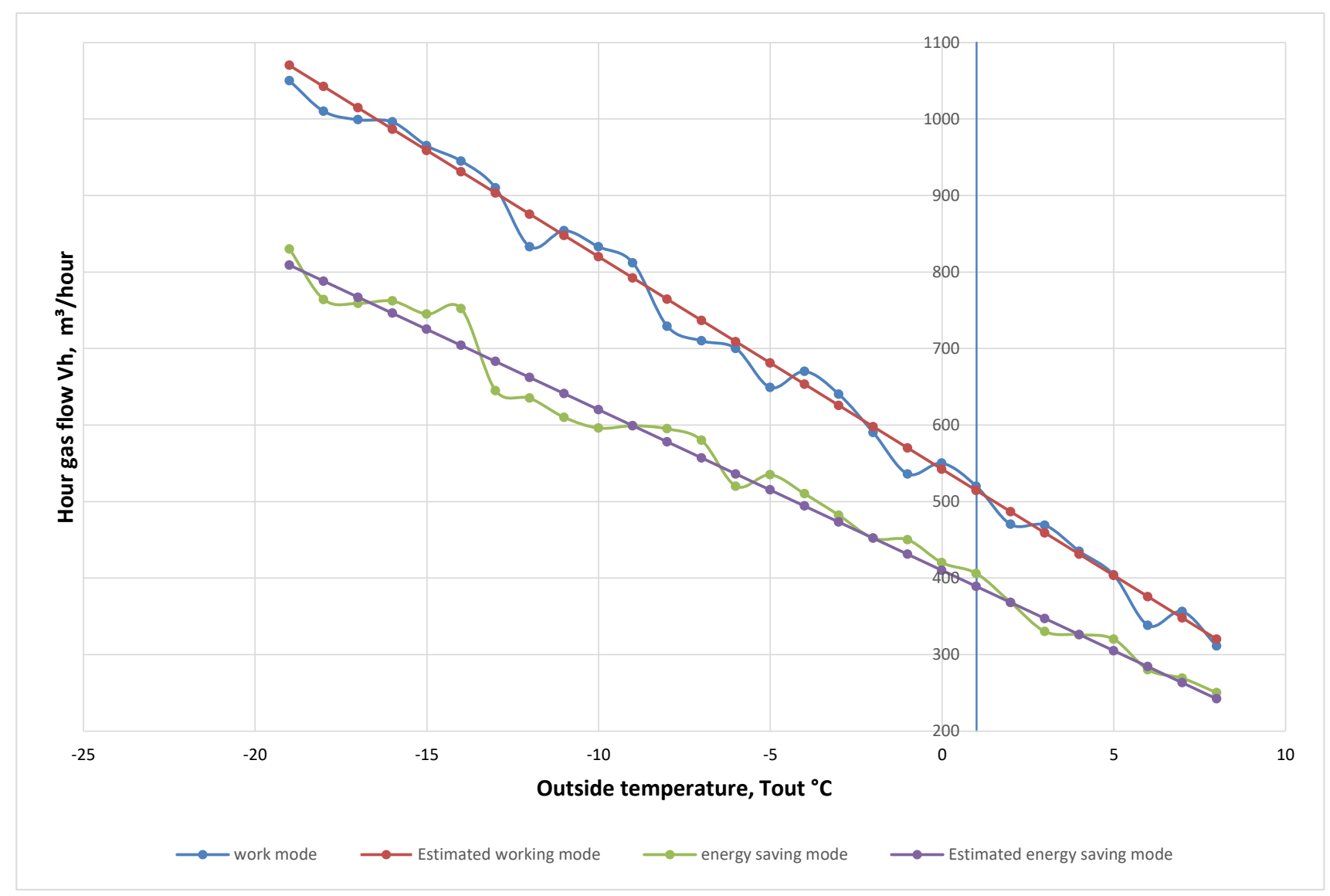

Fig.2. Dependence of the actual use of gas on the outside air temperature.

Then the hourly heat load $Q_{\text {mid.h }}$ boiler room for each point of the schedule of quality control of the coolant temperature can be determined by the formula:

$$
Q_{\text {mid.h }}=\frac{Q_{\text {mid. }} \times\left(t_{\text {in.f. }}-t_{\text {out.hp.f }}\right)}{\left(t_{\text {in.f }}-t_{\text {out.c }}\right)}, \mathrm{Gcal} / \mathrm{h},
$$

where $t_{\text {in.f }}$ is the actual average indoor temperature in the premises per hour (for the operating mode $t_{\text {in.f }}=18{ }^{\circ} \mathrm{C}$, for the economy mode during the holidays $t_{\text {in.f }}=12^{\circ} \mathrm{C}$ ); $t_{\text {out.hp.f }}$ is the actual average outdoor temperature per hour $\left(+8{ }^{\circ} \mathrm{C}\right.$ to $\left.-19{ }^{\circ} \mathrm{C}\right)$.

In a similar way, the required heat loads for the range of internal temperatures $t_{\text {in.f }}$ from $+18{ }^{\circ} \mathrm{C}$ to $+12{ }^{\circ} \mathrm{C}$ were determined. According to the results of calculations, a graphical dependence of the heat load of the boiler room on the outside air temperature is constructed (Fig.3). The graph shows that when $t_{\text {in.f }}$ decreases from $+18{ }^{\circ} \mathrm{C}$ to $+12{ }^{\circ} \mathrm{C}$, the heat load at an outdoor air temperature of $-19{ }^{\circ} \mathrm{C}$ decreases by $16.2 \%$, and for an outdoor air temperature of $+8{ }^{\circ} \mathrm{C}$ by $59,7 \%$. The average percentage reduction in heat load in the range of outdoor air temperatures from $+8{ }^{\circ} \mathrm{C}$ to $-19^{\circ} \mathrm{C}$ is $37.95 \%$.

As a result of research, it was found that to meet the needs of educational buildings in heating at $t_{\text {in. }}=+18{ }^{\circ} \mathrm{C}$ enough one boiler TVG-8 M, which is confirmed by actual data from shift logs and gas metering data.

The determined heat loads were then used to determine the required amount of gas required to maintain a particular temperature in the premises, depending on the accepted work schedule at the university. 


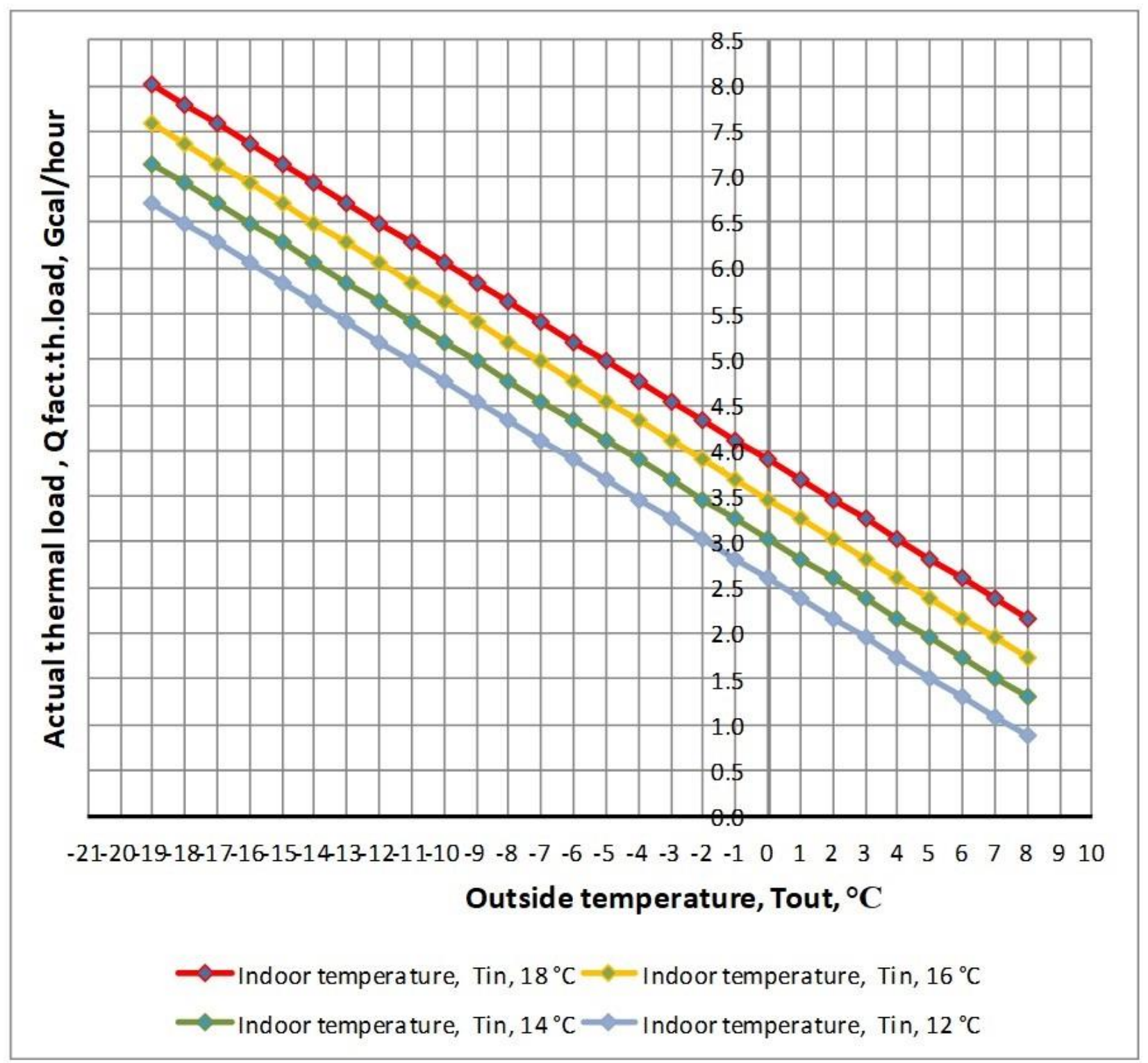

Fig.3. Dependence of heat load of the boiler room on the outside air temperature and indoor air temperatures in the premises from +12 to $+18^{\circ} \mathrm{C}$.

Based on the calculated needs for thermal energy for heating educational buildings, the hourly gas consumption was determined to provide heat load taking into account the temperature schedule in the range of outdoor air temperatures from $+8{ }^{\circ} \mathrm{C}$ to $-19{ }^{\circ} \mathrm{C}$ using the dependences [23]:

$$
V_{g}=\frac{Q_{\text {mid.h }} \times 1000000}{Q_{n} \times \eta_{\text {bruto }}}, \mathrm{m} 3 / \mathrm{h},
$$

where $V_{g}$ is hourly gas consumption, $\mathrm{m}^{3} / \mathrm{h} ; Q_{n}$ is lower heat of gas combustion $\left(8050 \mathrm{kcal} / \mathrm{m}^{3}\right) ; \eta_{\text {bruto }}$ is boiler efficiency, relative units (0.9).

The result is a graphical dependence of the hourly gas consumption in the boiler room in the temperature range $t_{\text {in.f }}$ from $+18^{\circ} \mathrm{C}$ to $+14^{\circ} \mathrm{C}$ shown in Fig. 4 . 


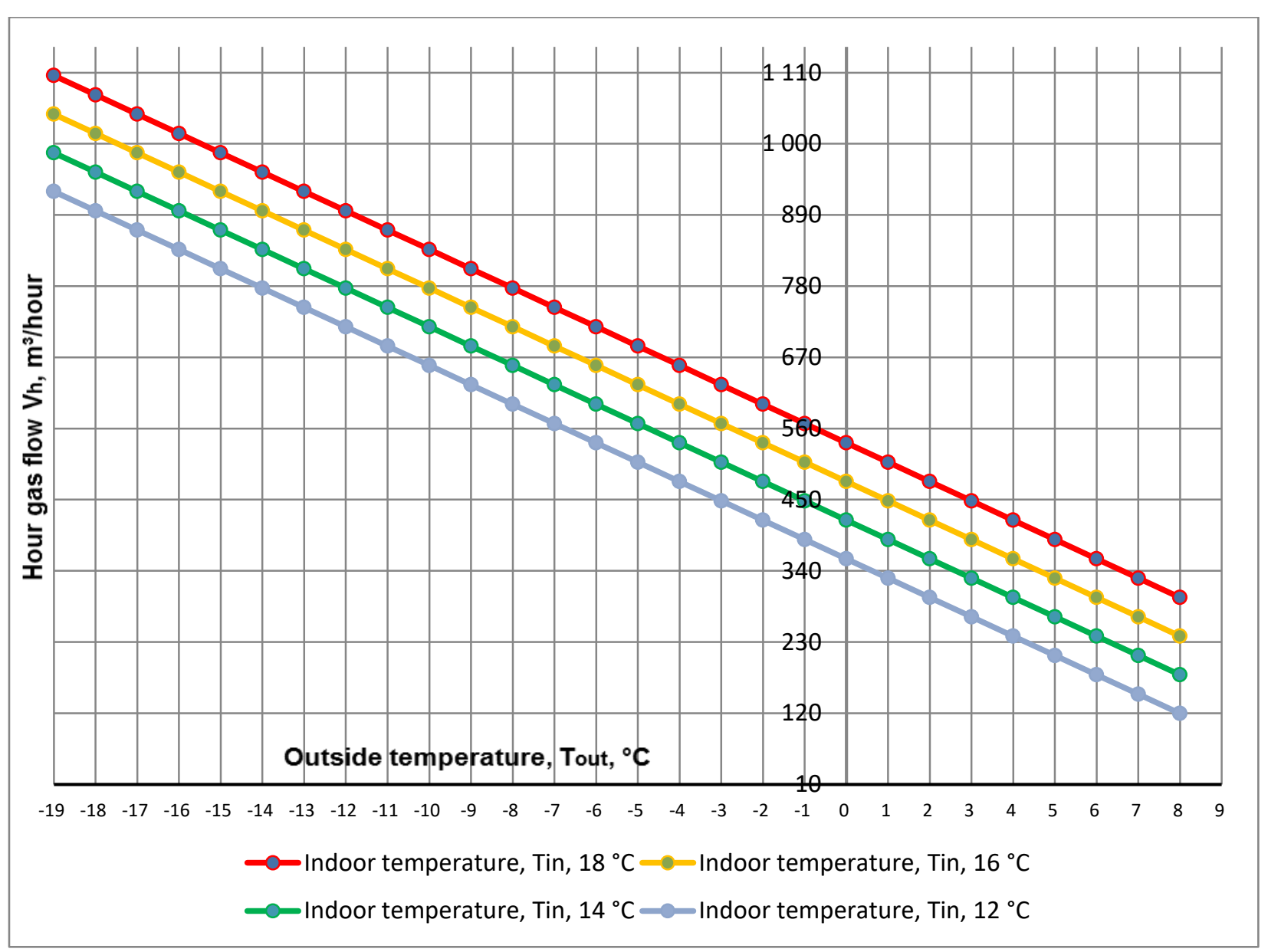

Fig.4. Dependence of boiler gas consumption on the outside air temperature and indoor air temperatures from $+12{ }^{\circ} \mathrm{C}$ to $+18^{\circ} \mathrm{C}$

It can be seen from the dependences that when the $t_{\text {in.f }}$ decreases from $+18{ }^{\circ} \mathrm{C}$ to $+12{ }^{\circ} \mathrm{C}$, the hourly gas consumption decreases by $16.1 \%$ for the external temperature of $-19{ }^{\circ} \mathrm{C}$, and for the external temperature of $+8{ }^{\circ} \mathrm{C}$ by $59.9 \%$. The average value of the reduction of natural gas consumption by the boiler house for the range of outdoor air temperatures from $+8{ }^{\circ} \mathrm{C}$ to $-19^{\circ} \mathrm{C}$ is $38 \%$.

Analysis of gas consumption data for previous periods confirmed that for the actual outdoor air temperatures $t_{\text {out.hp.f }}$ such gas consumption was indeed observed, which is evidence that the calculations were performed correctly.

Similarly, the required heat loads and gas consumption were determined to ensure the indoor air temperature $t_{\text {in.f }}=+12{ }^{\circ} \mathrm{C}$ in the premises of the educational buildings at the proposed mode of gas savings by reducing the air temperature in the premises from $t_{\text {in.f }}=+18{ }^{\circ} \mathrm{C}$ to $t_{\text {in.f }}=+12{ }^{\circ} \mathrm{C}$, the so-called economical mode of operation of the boiler room.

It should be noted that the above theoretical studies were compared with the actual data of the graph in Fig. 2, for the main mode of operation of the boiler, as a result it was found that the gas flow rate at ambient temperature $t_{\text {out.hp.f }}=-19{ }^{\circ} \mathrm{C}$ differs by $3.17 \%$, and the gas flow rate $t_{\text {out.hp.f }}=+8{ }^{\circ} \mathrm{C}$ differs by $6.56 \%$. The greater difference in the values of gas consumption at lower ambient temperatures can be explained by the fact that the actual gas flow corresponds to the required coolant temperature of $38^{\circ} \mathrm{C}$ according to the quality control schedule, respectively in this case the efficiency of the boiler is lower.

Based on the above, it should be noted that in order to increase the accuracy of calculations, the actual graph can be used to determine the actual gas savings in real conditions when $t_{\text {in.f }}$ drops from $+18{ }^{\circ} \mathrm{C}$ to $+12{ }^{\circ} \mathrm{C}$. 


\section{Conclusion}

During the experiment during January-February 2019, indoor air temperatures in educational buildings were measured in gas saving mode, and the actual gas consumption for each specific outdoor air temperature was compared with the data of the actual schedule of gas consumption for previous periods. During the experiment, the air temperature in the premises of educational buildings ranged from $+10{ }^{\circ} \mathrm{C}$ to $+13{ }^{\circ} \mathrm{C}$. And gas savings were:

- For January 2019 - 43.74\%, with an average monthly outdoor temperature of $-2.6^{\circ} \mathrm{C}$ (according to boiler temperature meters);

- For February 2019 (from 1 to 21 February) - 54\% at an average monthly outdoor temperature of $+3.2{ }^{\circ} \mathrm{C}$ (according to boiler room temperature meters).

- Introduction of methods of saving thermal energy and, accordingly, natural gas by introducing long vacations in educational institutions allows obtaining savings in the range from $43.74 \%$ to $54 \%$, which significantly exceeds the results of savings when using the intermittent heating mode. When the internal temperature of the premises in educational buildings drops from $+18{ }^{\circ} \mathrm{C}$ to $+12{ }^{\circ} \mathrm{C}$, the theoretical reduction in the need for thermal energy at an outdoor temperature of $-19^{\circ} \mathrm{C}$ is $16.2 \%$, and at an outdoor temperature of $+8^{\circ} \mathrm{C}$ is $59.7 \%$. The obtained results of actual gas savings of $43.74 \%$ in January 2019 and 54\% in the period from 1 to 20 February 2019 are in the range of theoretical savings from $16.2 \%$ to $59.7 \%$, which indicates the coincidence of theoretical calculations and actual results. The value of gas savings as a percentage will increase as the outside air temperature increases from $16.2 \%$ at $19{ }^{\circ} \mathrm{C}$, to $59.7 \%$ at $+8{ }^{\circ} \mathrm{C}$. The discrepancy between the actual and theoretical data on gas consumption will be in the range of $3.17 \%$ at an outdoor temperature of $-19{ }^{\circ} \mathrm{C}$ and $6.56 \%$ at an outdoor temperature of $+8{ }^{\circ} \mathrm{C}$. Based on the above, we can conclude that the maximum possible gas savings by lowering the indoor temperature in the premises from $+18{ }^{\circ} \mathrm{C}$ to $+12{ }^{\circ} \mathrm{C}$ is $59.7 \%$ when using district heating and energy conversion efficiency of boilers $90 \%$, and its specific value will be determined by outdoor temperatures within the period of lowering the indoor temperature in buildings.

\section{References}

[1] Shevchenko O.O. Realization of the organizational component of the mechanism of resource saving in higher educational institutions of Ukraine / O.O. Shevchenko // Bulletin of Kyiv National University of Technology and Design. Economic Sciences Series. - Special. Issue: Materials VII International. scientific-practical conf. "The effectiveness of the organizational and economic mechanism of innovative development of higher education in Ukraine" (October 6, 2017). - 2017. - P. 322-333. (in Ukrainian)

[2] Goncharenko I.M. Realization of energy efficiency potential as a direction of increasing the level of energy security of higher educational institutions / I.M. Goncharenko // Bulletin of Kyiv National University of Technology and Design. No.5 (79). 2014. - P. 11-16. (in Ukrainian)

[3] Dmitrichenko M.F. Implementation of energy-saving technologies in the national transport university / M.F. Dmitrichenko, M.M. Dmitriev, O.I. Bulakh // Bulletin of Kyiv National University of Technology and Design. No.6. 2013. - P. 156-158. (in Ukrainian)

[4] Klimenko L.P. L.P. Klymenko, O.P. Meshchaninov, V.I. Andreyev, O.V. Shchesyuk, L.V. Shchesyuk // Experience of using solar energy for hot water supply at Petro Mohyla Black Sea State University [Electronic resource]. Scientific works of Petro Mohyla Black Sea State University. Ser .: Technogenic safety. - 2012. - T. 203, Vip. 191. - P. 10-16. (in Ukrainian)

[5] Korpanyuk M.S. Energy efficiency of combined heating systems of educational institutions with the use of heat pumps [Electronic resource] / M.S. Korpanyuk, G.S. Ratushnyak // Proceedings of the XLVII Scientific and Technical Conference of VNTU, Vinnytsia, March 14-23, 2018 - Electron. text. data. - 2018. (in Ukrainian)

[6] Nakashidze L.V. The complex system of energy saving in educational building using active energy shields and alternative energy / L.V. Nakashydze // Bulletin of Kiev National University of Technology and Design. No.6. 2013. - P. 140-145. (in Ukrainian)

[7] Grishchenko I.M. Theoretical approaches to managing the efficiency of resource consumption in educational activities as a key factor in increasing the competitiveness of higher education institutions in Ukraine. / I.M. Gryshchenko, O.O. Shevchenko // Bulletin of the Kyiv National University of Technology and Design. Economic Sciences Series. - Special. issue: Materials VI International. scientific-practical conf. "The effectiveness of the organizational and economic mechanism of innovation-development of higher education in Ukraine "(October 7, 2016). - 2016. - C. 314-322. (in Ukrainian)

[8] Denisenko M.P. Peculiarities of performance management in higher educational institutions in the context of economical energy consumption / M.P. Denisenko, G.S. Zhulai // Bulletin of Kyiv National University of Technology and Design. No.6. 2013. - P. 99-107. (in Ukrainian)

[9] Safiulina K.R. Energy saving on campus: a guide. for higher educational institutions / K.R. Safiulina, A.G. Kolienko, R.Yu. Tormosov. Kyiv: Polygraph Plus, 2010. - 328 p. (in Ukrainian)

[10] Denisyuk S.P. Integrated energy management systems as a basis for building a modern energy efficiency policy of higher education institutions / S.P. Denisyuk, O.V. Borychenko // Bulletin of Kyiv National University of Technology and Design. No.6. 2013. - P. 212-220. (in Ukrainian)

[11] Deshko V.I. Conceptual model of management of energy consumption and energy saving processes in the field of education / V.I. Deshko. Deshko, O.M. Shevchenko // Bulletin of Kyiv National University of Technology and Design. No.6. 2013. - P. 201-205. (in Ukrainian) 
[12] Rosen V.P. Scientific - methodical approach for the analysis of efficiency of energy consumption by premises of educational institutions Rosen, O.V. Samkov, V.I. Lytvyn // Bulletin of Kyiv National University of Technology and Design. No.6. 2013. - P. 150-155. (in Ukrainian)

[13] Shovkalyuk M.M. Analysis of energy efficiency and assessment of the impact of operational factors of educational buildings / M.M. Shovkalyuk, N.O. Voynalovych // Scientific Journal "Energy: Economics, Technology, Ecology", KPI, No. 4, 2015. - P. 100-105. (in Ukrainian)

[14] Shovkalyuk M.M. Application of regression dependences for forecasting heat consumption of educational buildings / Shovkalyuk M.M., Voynalovych N.O. // Scientific journal "Young scientist", No.5 (20), 2015. P. 57-61. (in Ukrainian)

[15] Zakharchekno Yu.A. Automation of energy efficiency management of educational institutions of the budget sphere / Yu.A. Zakharchenko, Sokolova N.P., Maslennikov S.V. // Bulletin of Kyiv National University of Technology and Design. No.6. 2013. - P. 31-39. (in Ukrainian)

[16] Kaplun V.V. Evaluation of energy efficiency of electrical complexes of higher educational institutions on the basis of standardization of specific indicators of electricity consumption // Bulletin of the Kyiv National University of Technology and Design. Series "Technical Science". No.5 (90). 2014. - P. 59-70. (in Ukrainian)

[17] Chornovol M.I. Increasing the level of energy efficiency of a technical university by optimizing the energy balance / M.I. Chornovol, P.G. Pleshkov, S.V. Serebrennikov, I.V. Savelenko, K.G. Petrova // Bulletin of Kyiv National University of Technology and Design. Series "Technical Science". No.5 (90). 2015. - P. 99-105. (in Ukrainian)

[18] Chornovol M.I. Increasing the efficiency of energy supply of Kirovograd National Technical University on the basis of energy balance optimization / M.I. Chornovol, V.K. Grabenko, P.G. Pleshkov // Bulletin of the Kyiv National University of Technology and Design. No. 5. 2013. - P. 94-99. (in Ukrainian)

[19] Basok B.I. The efficiency of intermittent space heating / B.I .Basok, B.V. Davydenko, S.M. Goncharuk, O.P. Lysenko // Industrial Heat Engineering. - 2013. - V. 35, No. 6. - P. 39-46. (in Russian)

[20] State building codes DBN B.2.5-67: 2013 "Heating, ventilation and air conditioning". Kyiv, Ministry of Regional Development of Ukraine, 2013, 141p. (in Ukrainian)

[21] Norms and guidelines for standardization of fuel and thermal energy consumption for heating of residential and public buildings, as well as for household needs in Ukraine. KTM 204, Kyiv, 2001, 376p. (in Ukrainian)

[22] Intersectoral norms of consumption of electric and thermal energy for institutions and organizations of the budget sphere of Ukraine. Kyiv, 2000, 103p. (in Ukrainian)

[23] Handbook of the operator of gasified boiler rooms / L. Ya. Poretsky, R.R. Rybakov, E.B. Stolpner, etc. - 2nd ed., Reworked and extra. - L.: Nedra, 1988. 608p. (in Russian)

\title{
Оцінка заходів економії природного газу в державних навчальних закладах
}

\author{
Володимир Пашкевич, Юрій Фурдас, Володимир Крайовський, Василь Желих
}

Національний університет “Львівська політехніка”,вул. Степана Бандери 12, м. Львів, 79013, Украӥна

\section{Анотація}

В статті проаналізовано відомості витрати газу за періоди опалювання та підтверджено, що для фактичних температур зовнішнього повітря спостерігається зменшення витрати газу. Були визначені необхідні теплові навантаження і витрати газу для забезпечення необхідної температури внутрішнього повітря в приміщеннях навчальних корпусів при запропонованому режимі економії газу за рахунок пониження температури повітря в приміщеннях, так званий, економний режим роботи котельні. Визначено теоретичну економію газу від пониження температурного режиму. Для підвищення точності експерименту порівняння кількості спожитого газу проводилось в розрізі робочих і неробочих періодів доби. Виходячи 3 даних досліджень слід відмітити, побудований фактичний графік можна використовувати для визначення фактичної економії газу в реальних умовах.

Ключові слова: котельня; температура повітря; котельний газ; природний газ. 